Summer 6-2013

\title{
Linking Distributive and Procedural Justice to Employee Engagement Through Social Exchange: A Field Study in India
}

\author{
Soumendu Biswas \\ Management Development Institute, Gurgaon, India \\ Arup Varma \\ Loyola University Chicago, avarma@luc.edu \\ Aarti Ramaswami \\ ESSEC Business School, Cergy-Pontoise, France
}

Follow this and additional works at: https://ecommons.luc.edu/business_facpubs

Part of the Human Resources Management Commons, and the International Business Commons

\section{Author Manuscript}

This is a pre-publication author manuscript of the final, published article.

\section{Recommended Citation}

Biswas, Soumendu; Varma, Arup; and Ramaswami, Aarti. Linking Distributive and Procedural Justice to Employee Engagement Through Social Exchange: A Field Study in India. The International Journal of Human Resource Management, , : , 2013. Retrieved from Loyola eCommons, School of Business: Faculty Publications and Other Works, http://dx.doi.org/10.1080/09585192.2012.725072

This Article is brought to you for free and open access by the Faculty Publications and Other Works by Department at Loyola eCommons. It has been accepted for inclusion in School of Business: Faculty Publications and Other Works by an authorized administrator of Loyola eCommons. For more information, please contact ecommons@luc.edu.

\section{(c) $($ () $\ominus$}

This work is licensed under a Creative Commons Attribution-Noncommercial-No Derivative Works 3.0 License. (c) 2013 Taylor \& Francis. 
Running Head: JUSTICE, SOCIAL EXCHANGE, AND EMPLOYEE ENGAGEMENT

LINKING DISTRIBUTIVE AND PROCEDURAL JUSTICE TO EMPLOYEE ENGAGEMENT THROUGH SOCIAL EXCHANGE: A FIELD STUDY IN INDIA

Soumendu Biswas

Department of Human Resource Management, Management Development

Institute, Gurgaon, India;

Arup Varma

Quinlan School of Business, Loyola University Chicago, Chicago, USA

Aarti Ramaswami

Department of Management, ESSEC Business School, Cergy-Pontoise, France

Published in

International Journal of Human Resource Management,

Vol. 24(8), pp. 1570-1587. (2013) 


\title{
LINKING DISTRIBUTIVE AND PROCEDURAL JUSTICE TO EMPLOYEE ENGAGEMENT THROUGH SOCIAL EXCHANGE: A FIELD STUDY IN INDIA
}

\author{
ABSTRACT \\ Research linking justice perceptions to employee outcomes has referred to social exchange as its \\ central theoretical premise. We tested a conceptual model linking distributive and procedural \\ justice to employee engagement through social exchange mediators, namely, perceived \\ organizational support and psychological contract, among 238 managers and executives from \\ manufacturing and service sector firms in India. Findings suggest that perceived organizational \\ support mediated the relationship between distributive justice and employee engagement, and \\ both perceived organizational support and psychological contract mediated the relationship \\ between procedural justice and employee engagement. Theoretical and practical implications \\ with respect to organizational functions are discussed.
}

KEYWORDS: distributive justice, procedural justice, POS, psychological contract, employee engagement, social exchange, India 
The increasing volatility and complexity of global business have ushered in an era where firms are under pressure to retain talent as well as gain and sustain their competitive advantage. Indeed, within this context, there is an increasing need to study employee-organization social exchange and its impact on individual and organizational outcomes (Biswas \& Varma, 2007; Tsui, Pearce, Porter, \& Hite, 1995). Additionally, prior research has indicated that within the framework of social exchange theory (SET), organizational justice would be directly associated with the quality of social exchange between individuals and their organizations and also organizational agents such as immediate supervisors (Bhatnagar \& Biswas, 2010).

Organizational justice, which represents employees' observed fairness at the workplace, governs their social exchange relationships (Kashyap, Ribeiro, Asare, \& Brashear, 2007). We test hypotheses proposing social exchange variables such as perceived organizational support (POS) (Eisenberger, Huntington, Hutchison, \& Sowa, 1986) and psychological contract as mediators of the relationship between distributive and procedural justice and employee engagement. Distributive justice refers to the apparent impartiality that employees perceive in the allocation of rewards and recognition by their employing organization (Byrne \& Cropanzano, 2001); procedural justice investigates the reasonability of the rewards allocation process (Thibaut \& Walker, 1975). Employees' sensitivity regarding distributive justice predicts the degree to which they perceive their organization to value their contribution and take care of them, or in other words, their perceived organizational support (POS) (Masterson, Lewis, Goldman, \& Taylor, 2000). Similarly, the fairer the employees' opinions about procedural justice, the stronger their perception that the organization has maintained norms of psychological contract, thus enhancing socio-emotional bonds between them (Tekleab, Takeuchi, \& Taylor, 2005).

This study makes theoretical, research as well as practical contributions. From a theoretical perspective, given that organizational justice and employee engagement are based on 
obligations created through perceptions of reciprocal interdependence, SET provides an appropriate theoretical framework for investigating associations between them. This is supported by research suggesting POS and psychological contract as key variables used to operationalize social exchange relations and explain outcomes of organizational justice as well as antecedents of employee engagement (Cropanzano \& Mitchell, 2005; Rousseau, 1995). Yet, "it is unfortunate that research has yet to examine the relevant justice and social exchange variables within one study" (Masterson, et al., 2000, p. 738). That POS and psychological contract are increasingly important variables within SET have come out of three distinct streams of research: (1) investigations regarding associations between organizational justice and social exchange relationships (Rupp \& Cropanzano, 2002); (2) the explanatory power of social exchange in providing a significant basis for employee engagement; and (3) research related to associations between POS and psychological contract and employee engagement (Aselage \& Eisenberger, 2003). Indeed, by investigating the mediating role of POS and psychological contract between organizational justice and employee engagement, our research contributes to these distinct albeit interconnected conceptual areas.

From a research perspective, the study extends the sampling frame and context of justice, social exchange, and employee engagement research by testing hypotheses among Indian managers and executives. Indeed, over the last two decades, India has gained increasing importance in the world economic scene, due to its steady rise as well as opening up of its markets, following liberalization and reforms initiated in 1991 (Budhwar \& Varma, 2011).

As one might expect, the liberalization of the Indian economy and the resultant growth in competition among firms has led to significant changes in managerial policies and procedures, especially those related to human resource (HR) functions (Budhwar \& Sparrow, 1998; Sparrow \& Budhwar, 1997). One clear outcome has been the shift in emphasis from day-to-day operations 
to strategic initiatives (Budhwar, 2001; Yadapadithaya, 2000). As a result, policies such as performance-linked compensation, employer branding activities, talent acquisition and employee engagement initiatives are now commonplace (Bhatnagar \& Biswas, 2010). Further, the advent of multinationals in India has made Indian employees aware of international standards and practices as these relate to HR issues. Thus, employees now want a more participative and fair environment, thus making justice issues critical in the workplace.

Finally, from a practical perspective, for consultants and HR practitioners, this study has a variety of implications. For example, an exchange-based framework, as proposed in this study, would help managers understand the past attitudinal differences between employees who are psychologically and cognitively occupied with their work and those who suffer excessively from disenchantment, stress, and burnout. In addition, by boosting employees' perception of justice through provisions of employee care and well-being and forbidding discernments regarding organizational contract violation, managers may elicit greater employee engagement. This in turn may positively influence more distal outcomes including job satisfaction, trust, and reduced turnover intentions.

\section{Theoretical Framework and Hypotheses}

\section{Distributive Justice}

As Greenberg (1990, p. 399) observed, "[justice] is a basic requirement for the effective functioning of organizations and the personal satisfaction of the individuals they employ." Distributive justice has roots in equity theory (Adams, 1965) wherein social exchange underlies relationships between employees and employers. While employees contribute their time and effort for the organization, employers compensate them through appropriate rewards and recognition. In this context, employees' opinion about equity or inequity is based on their social comparison with a referent individual or group. The perceived input-output ratio of what 
employees receive for their contribution vis-à-vis referent individuals or groups decides equity or inequity (Folger \& Cropanzano, 1998). Distributive justice would be achieved if not only rewards but also punishments are meted out impartially, as the focus is on fairness perceptions. Thus, as a result of input-output ratio comparisons, individuals exert more or less effort, altering their organizational participation.

Distributive justice has been found to predict workers' satisfaction with compensation and benefits, and job attitudes including job satisfaction (Cohen-Charash \& Spector, 2001; Colquitt, Conlon, Wesson, Porter, \& Ng, 2001), and turnover intentions (Konovsky \& Cropanzano, 1991). In this connection, research suggests that justice is significantly associated with social exchange (Greenberg \& Scott, 1996). SET stresses that the interrelation between employees and their organizations leads to mutual obligations, and fulfillment of these obligations can lead to perceptions of organizational support and failure to meet them can lead to perceptions of organizational disidentification (Blau, 1964). The main premise of SET is the norm of reciprocity wherein employees who perceive the distribution of rewards and resources to be fair and equitable extend it to POS and, in turn, return the favour by being cognitively, physically, and emotionally engaged in their work and workplace. For example, Rhoades and Eisenberger's (2002) meta-analysis also found that POS is a significant consequence of fair treatment at work, job conditions, and positive levels of supervisor support. In other words, POS may be an important outcome of distributively just practices. Based on the above discussion, we present the first hypothesis as follows.

Hypothesis 1: Distributive justice is positively related to POS.

\section{Procedural Justice}

Procedural justice refers to employees' conceptions regarding the fairness of the formal procedures used to distribute rewards and benefits at work (Thibaut \& Walker, 1975). 
Accordingly, fairness of managerial policies and practices, especially HR practices, form the informational source of employees' perceptions of procedural justice (Kuvaas, 2008), which shapes their cognizance of the various organizational, group, or individual outcomes (Bowen \& Ostroff, 2004; Brockner, 2002). Employees who feel that their organizational decision-making and other related processes are impartial and nondiscriminatory will be motivated to comply with organizational requests and requirements (Bies, 2005).

Procedural justice predicts various employee attitudinal and behavioral outcomes including, task performance, rule compliance, cooperation, and deference to authority (Colquitt, 2001; Colquitt, Greenberg, \& Scott, 2005). However, there has been a paucity in explanations regarding relationships involving reciprocal norms in organizations. As noted earlier, employees' opinions regarding the fairness of decision making as well as the processes by which they are made induces them to believe that the organization cares for them and is concerned about their welfare (Moorman, Blakely, \& Niehoff, 1998). Studies (e.g. Moorman \& Byrne, 2005) have also suggested POS as a link between procedural justice and various employee level outcomes including organizational citizenship behaviour, organizational commitment, and organizational identification, because employees perceive organizational activities favorably towards them when they observe fairness in processes and practices (Eisenberger, Armeli, Rexwinkel, Lynch, \& Rhoades, 2001). Accordingly, we propose our second hypothesis. Hypothesis 2: Procedural justice is positively related to POS.

When employees view decision-making procedures to be accurate, consistent, unbiased, and correctable they perceive organizational systems as following processes that meet justice criteria (Colquitt, Scott, Judge, \& Shaw, 2006). Even while explaining unfair or inconsistent justice procedures, organizations which allow employees to voice their dissatisfaction and propose suggestions regarding it ultimately led to stronger bonding between individuals and 
organizations (Colquitt \& Chertkoff, 2002). This is because, according to fairness theory and the relational model of justice, fairness in the process of mitigating allocation of outcomes conveys the message that employees are valuable to the organization. This boosts their self-esteem and self-worth and assures them that they are being given due attention in return for their services (Colquitt \& Chertkoff, 2002). Thus, procedural justice enhances perceptions of mutual obligations between employer and employees as it strengthens idiosyncratic beliefs arising out of cognitive appraisals of circumstances (Rousseau, 1995).

Additionally, organizational support theory (OST) suggests that employees sometimes ascribe humanlike attributes to their organizations and actions taken by organizational agents such as managers are viewed as the organizations' intentions (Aselage \& Eisenberger, 2003; Rhoades \& Eisenberger, 2002). In keeping with OST, employees interpret organizational activities such as HR practices as indicative of the organization's commitment towards them (Settoon, Bennett, \& Liden, 1996). Based on such anthropomorphism, employees view fair or unfair practices and procedures of the organization as indicators of the degree to which the latter values the contribution made by the former and cares about the former's well-being. Thus, within the OST framework, there appears to be an association between employees' perceptions regarding procedural justice and psychological contract. Consequently, our third hypothesis is as follows.

Hypothesis 3: Procedural justice is positively related to psychological contract.

\section{POS, Psychological Contract, and Employee Engagement}

POS refers to employees' opinions regarding the extent to which their employing organization considers their aspirations and helps them achieve their goals and objectives (Kuvaas, 2008). As per SET, employees who perceive high levels of POS develop a 'felt obligation' towards their organization and tend to repay them through positive attitudes and 
relevant behaviours (Coyle-Shapiro \& Conway, 2004). This is perhaps because POS allows employees to feel that their organizations value their work, that they are optimally using job resources, which in turn fuels their engagement at work. Conversely, a lack of POS has been consistently found to be associated with burnout and stress (Schaufeli \& Baker, 2004). Thus, within the premise of SET, when employees deem their organization to be supportive and caring about their well-being they respond by endeavoring to execute their obligations and responsibilities and becoming more engaged (Rhoades \& Eisenberger, 2002). However, a direct association between POS and employee engagement has been difficult to find. Our present study realizes this lacuna (with the possible exception of Saks, 2006) and proposes the following hypothesis:

Hypothesis 4: POS is positively related to employee engagement.

Conversely, factors that reduce meaning in one's work can lead to disaffection or disengagement from one's work (Atkouf, 1992). The formation of employees' psychological contract is shaped by company policies related to recruitment, compensation, and claims along with social cues from the work environment (Boxall \& Purcell, 2000). Positive levels of promissory expectations regarding workplace relationships has been shown to create stable and durable schemata that lead to heightened cognitive, behavioral, and psychological meaningfulness at work (Fiske \& Taylor, 1984). According to McBain (2007), fulfillment of psychological contract creates an emotional connect between organizations and their members leading to superior performance vis-à-vis in-role activities, release of discretionary efforts, and ultimately realization of individual as well as organizational goals and objectives. Thus, fulfillment of psychological contract, as perceived by individual employees, ends with their being more engaged with their work.

Hypothesis 5: Psychological contract is positively related to employee engagement. 


\section{The Mediating Role of POS and Psychological Contract}

According to SET, organizations are forums for transactions (Blau, 1964). Specifically, this theory suggests that there are primarily two kinds of exchange. First, there are economic exchange relationships that are based on relatively overt and quid pro quo understanding of mutual duties and responsibilities. According to Cropanzano and Prehar (2001) such exchanges comprise a single or an allied cycle of short term exchanges. However, more related to this study are social exchange relationships. Unlike their economic counterpart, social exchange relationships are typified by affective regards, communal uniqueness, and a sense of allegiance (Masterson, et al., 2000). Organizational justice dimensions facilitate the configuration of social exchange relations and these in turn incite employees to higher levels of attachment and involvement with their work and workplace (Cropanzano et al., 2002). In fact, evidence indicates that social exchange relationships mediate the link between justice dimensions and employee attitudes and behaviours and to some extent our study replicates such results. We present our mediation hypotheses as follows.

Hypothesis 6a: POS mediates the relationship between distributive justice and employee engagement.

Hypothesis 6b: POS mediates the relationship between procedural justice and employee engagement.

Hypothesis 6c: Psychological contract mediates the relationship between procedural justice and employee engagement.

Based on the above review and discussion, the latent variable model (LVM1) of our study is presented in Figure 1.

Insert Figure 1 about here 


\section{Method}

\section{Sample}

For this study, we collected data from managers and executives from 12 organizations all over India. Of these 12 organizations, five belonged to the manufacturing sector, including steel manufacturing, cable makers, refractories, cement manufacturing, and pharmaceutical organization. The remaining seven belonged to the service sector corresponding to insurance, private and public sector banks, telecommunications, information technology, information technology enabled services, and management consultancy. These organizations were randomly selected from various databases such as Yellow Pages Business Directory, Centre for Monitoring Indian Economy (CMIE) database, and so on. We contacted HR departments of the selected firms and obtained permission to collect data.

On agreeing to carry out our research, we distributed a total of about 600 survey forms in these organizations. Of these 600 forms, we received a total of 238 usable responses (response rate of $39.7 \%$ ). Out of the 238 participants, $45.80 \%$ belonged to the manufacturing sector, and the rest belonged to the service sector; $74.4 \%$ were male, and average years of work experience was 9.4 years; average age of respondents was about 33 years, and the average hours worked per week was about 48. Seventy-six had undergraduate degrees, 135 had graduate degrees, and 19 were diploma holders (eight did not report their educational qualifications).

\section{Measures}

Unless otherwise specified, participants rated all items using a five-point scale where $1=$ strongly disagree to $5=$ strongly agree.

Organizational justice: We used Niehoff and Moorman's (1993) five-item scale for distributive justice $(\alpha=.80)$, and their six-item scale for procedural justice $(\alpha=.84)$. A sample item for distributive justice includes, "I consider my workload to be quite fair," and for 
procedural justice includes, "To make formal job decisions, my manager collects accurate and complete information."

Perceived organizational support: We used seven of the eight items by Rhoades, et al. (2001). We deleted the item, "The organization cares about my opinions," as it diminished scale reliability $(\alpha=.77)$. This is consistent with the findings of Hofstede (2001) regarding India's culture, which is characterized by high power-distance. A sample item includes, "The organization is willing to help me if I need a special favor."

Psychological contract: We used Raja, Johns, and Ntalianis' (2004) scale to measure both relational contract and transactional contract, with nine items for each $(\alpha=.77$ for combined scale). The reliability of the relational contract scale was .88 and that of the transactional contract was .77. Sample items included, "My commitment to this organization is defined by my contract," and, "I feel this company reciprocates the effort put in by its employees."

Employee engagement: We used Saks (2006) 11-item scale that takes into account both job engagement and organizational engagement comprising five and six items, respectively $(\alpha=$ .82 for combined scale). The reliability index of the job engagement scale was .70 and that of organizational engagement was .72. Sample items include, "I am highly engaged in this job," and, "One of the most exciting things for me is getting involved with things happening in this organization."

Control variables: In all analyses, age, tenure, amount of time spent with immediate supervisor, and respondent educational level were controlled for. Prior studies have demonstrated that these demographics are potential predictors of the study criterion (Ang, Dyne, \& Begley, 2003; Avolio, Zhu, Koh, \& Bhatia, 2004).

\section{Common Method Bias}


Given that all responses were provided by the same respondent, common method bias (Podsakoff, MacKenzie, Lee, \& Podsakoff, 2003) was a concern. Harman's single-factor test was conducted to address this. Items from all scales were included in a factor analysis to determine whether a single factor claimed a disproportionately large variance. Results suggested that there was no general factor that accounted for a majority of the variance. As such, it was concluded that common method bias is not present in this study.

\section{Analytical Procedure}

The proposed study is based on a recursive path model (see Figure 1), analysed using SPSS 17.0 and AMOS 17.0. Data analysis was done in two parts: (a) analysis of the measurement model through confirmatory factor analysis (CFA) and scale analysis to ensure reliability of the instruments, and (b) analysis of the path model using maximum likelihood estimation (MLE) in structural equation modeling (SEM). To test for mediation, the procedures suggested by MacKinnon, Warsi, and Dwyer (1995) were used.

\section{Results}

We conducted a confirmatory factor analysis to ascertain the distinctiveness of the measures of the study variables that is, distributive justice, procedural justice, POS, psychological contract, and employee engagement. We used AMOS to compare the fit of two nested models: (a) a one-factor model incorporating all the five the constructs and (b) a five-factor model characterizing the five study constructs separately. Based on the sequential chi-square difference test (James, Mulaik, \& Brett, 1982), the five-factor model, $\chi^{2}(224, N=238)=1150.5$, fit the data significantly better than the one-factor model, $\chi^{2}(230, N=238)=1735.7 ; \chi_{\text {diff }}^{2}(6, N=238)$ $=585.2, p \leq .01$. Therefore, we treated the five constructs as distinct in subsequent analyses.

\section{Descriptive Statistics and Correlation}


Means, standard deviations, internal reliabilities, and intercorrelations among the variables are reported in Table 1.

Insert Table 1 about here

Relationships of Distributive and Procedural Justice with POS, Psychological Contract, and Employee Engagement

We used AMOS to assess the degree to which distributive justice and procedural justice related to POS, psychological contract, and employee engagement, and whether POS and psychological contract mediated the relationship between the predictors and the criterion. The regression estimates, presented in Table 2, allowed us to examine the direct association between the analysis variables. The level of significance is based on the critical ratio (C.R.) of the regression estimate (Biswas, Giri, \& Srivastava, 2006). C.R. values $>=2.58$ indicate a $99 \%$ level of significance; C.R. values $>=1.96$ but $<2.58$ indicate a $95 \%$ level of significance. Distributive justice $(\beta=.37$, C.R. $=4.75)$ and procedural justice $(\beta=.46$, C.R. $=3.48)$ regressed significantly and positively on POS, consistent with Hypotheses 1 and 2. Further, procedural justice associated significantly and positively with psychological contract $(\beta=.75$, C.R. $=8.78)$, supporting Hypothesis 3. Finally, POS $(\beta=.28$, C.R. $=8.54)$ and psychological contract $(\beta=.51$, C.R. $=$ 3.29) associated significantly and positively with employee engagement, supporting Hypotheses 4 and 5.

Insert Table 2 and Figure 2 about here

To test the mediation of POS and psychological contract, we followed Wood, Goodman, Beckmann, and Cook (2008) and applied structural equation modeling (SEM) procedures using the maximum likelihood estimation (MLE) algorithm. It has been previously argued that in the 
area of mediation analysis, when variables with multiple indicators have been taken into account (Iacobucci, Saldanah, \& Deng, 2007), when conditions of confirmatory analyses have been met (James \& Brett, 1984), and when models have incorporated latent variables (Kenny, Kashy, \& Bolger, 1998), SEM offers a better alternative to traditional multiple regression tests of mediation. We consider four competing models namely, Latent Variable Model or LVM1 (Figures 1 and 2), LVM2 (Figure 3), LVM3 (Figure 4), and LVM4 (Figure 5). LVM1 includes the potential mediators that are, POS and psychological contract. LVM2 constrains the first mediator POS, and LVM3 constrains the second mediator, psychological contract. Finally, LVM4 examines the direct relation between the predictor and the criterion variables, that is, perceptions regarding the justice dimensions and employee engagement. We then use fit indices to compare models.

\section{Insert Figures 3 through 5 about here}

In addition to chi-square, widely accepted goodness-of-fit indices were considered to evaluate the models, including goodness-of-fit index (GFI), comparative-fit-index (CFI), normedfit-index (NFI), relative-fit-index (RFI), and Tucker-Lewis index (TLI). Values over .90 on these indices generally indicate acceptable fit (Bentler, 1990; Bentler \& Bonett, 1980; Hu \& Bentler, 1999). We also considered the parsimony of the competing models based on root mean square error of approximation (RMSEA) values, with recommended value of .08 or lower (Brown \& Cudeck, 1993). Finally, we also used the Akaike Information Criteria (AIC) for model selection and strengthened our claims by using the Browne-Cudeck (1989) criteria. Results of SEM analysis (Table 3) support Hypotheses 6a through 6c. While other causal models that might fit the data equally well, given the theoretical premises of this study, we found LVM1 to be the bestfitting model. 
Insert Table 3 about here

SEM results suggest POS and psychological contract as mediators, and precludes problems of correlated measurement error. Nevertheless, we further conducted Sobel's (1982), Aroian's (1944), and Goodman's (1960) tests in line with the z-prime method (MacKinnon, Lockwood, Hoffman, West, \& Sheetes, 2002) to check for the statistical power of our models and discount the possibility of Type I error while exploring the strength of mediation. Results of these tests are provided in Table 4.

Finally, we also performed the two-step procedure suggested by MacKinnon, et al. (1995) to categorize the status of POS and psychological contract as full- or quasi-mediators: (i) whether the direct paths from the antecedent to the consequents were greater than the paths under the condition of mediation, and, (ii) whether the direct path from the predictors to the criteria under the mediated condition was significant. Since, for POS, condition (i) was negative and condition (ii) was positive, we concluded that POS is a full-mediator between distributive and procedural justice and employee engagement. A similar test was performed for psychological contract as a mediator and the results obtained were similar (Table 4).

Insert Table 4 about here

\section{Discussion}

Despite a plethora of studies on employee engagement, little research exists with engagement as the criterion variable. In fact, prior literature is silent on the association between justice and engagement within or outside of the social exchange framework. To that end, our study highlights the antecedents of employee engagement. Employing the social exchange perspective, a conceptual model was developed and tested with data collected from 238 managers and executives in manufacturing and service sector firms in India. Importantly, our study 
contributes to existing literature on organizational justice, social exchange, and employee reactions. We establish distributive as well as procedural justice as primary determinants of POS, and procedural justice as a key antecedent of psychological contract in organizations. We further extend this chain of relationships by testing and supporting the mediating role of POS and psychological contract between justice perceptions and employee engagement.

These findings are consistent with prior literature using POS and psychological contract (e.g. Loi, Hang-yue, Foley, 2006) as social exchange mediators through which work experience variables such as distributive and procedural justice impact work attachment variables such as employee engagement. Furthermore, this study suggests that engagement is influenced by employees' perception of organizations' concern and fulfillment of promissory expectations as a result of equitable distribution and fair procedures. Thus, to ensure that employees are optimally engaged with their job, organizations must ensure policies and practices that reinforce employees' justice perceptions. Given the role of POS and psychological contract in the process of employee-organization exchange, organizations are required to employ actions that significantly augment POS and fortify the notion of psychological contract. Previous literature has emphasized procedural justice as the conspicuous means of explaining the employeeorganization exchange. Our findings suggest that, in addition to procedural justice, Indian managers and executives place strong emphasis on distributive justice perceptions when evaluating support from their employers. This highlights the implications of reward allocations for Indian employees in their organization. This finding corroborates with other related studies conducted in Asia (Ngo, Tang, \& Au, 2002; Pillai, Williams, \& Tan, 2001). Thus, distributive justice appears to play a noticeable role for them in scrutinizing their employing organization.

The present study also supports and extends existing social exchange literature by ratifying distributive justice as a significant predictor of perceptions of organizational support. 
Managers and executives may take suitable steps to ensure distributive justice through fair work norms and compensation. Additionally, managers would enrich job experiences and psychological availability of employees at the workplace by providing a just environment and enhancing social exchange mores. Study findings also suggest that in the absence of justice perceptions or social exchange, employees may suffer from disengagement at work leading to stress and burnout. In addition, this stresses the usefulness of obtaining high POS among managerial professionals. Our results further imply that organizational treatment has implications for the nature of employee-employer psychological contracts.

Notably, our study underscores that exploring the consequences of organizational justice without taking into account social exchange may lead to spurious conclusions (e.g. Manogran, Staufer, \& Conlon, 1994). In core, the foregoing discussion as well as results of Sobel's, Aroian's, and Goodman's tests highlight the importance of POS and psychological contract as explanatory social exchange variables for the effects of distributive and procedural justice on employee engagement.

\section{Implications for Practice}

To the extent that organizations show sincere efforts towards social exchange, they are less likely to have employees show detachment and disengagement. Hence, organizations would do well to invest in openly communicating management's values, beliefs, and norms so that employees have clear, unbiased impressions regarding their employers' attempts at being fair and concerned. By the same token, organizations' investment in training to increase the sensitivity of supervisor-subordinate interactions so that the former may be able to make the latter aware of the organization's efforts towards being fair in the procedures and nature of allocation of outcomes. In the absence of mechanistic structures and the emphasis being on organic structures in contemporary organizations in India where our study was conducted, we posit that such 
interactions may have positive effects. Besides, by maintaining valid justice perceptions among employees and increasing their workplace engagement by heightening social exchange efforts through appropriate interventions, managers would also be able to encourage self-expression, self-efficacy, and innovativeness among employees.

Practically, the study's results further suggest that managers should focus on organizational programs that address employee needs and concerns such as surveys, focus groups, and suggestion programs and those that demonstrate concern and support like flexible work arrangement. These, apart from convincing employees that their employers are fair and just would also make them believe that their employers are fulfilling promissory expectations. As a consequence, employees would increase their levels of engagement. Our findings also indicate that management would do well to get rid of any 'one size fits all' approach to employee supervision. Employee engagement is an enduring and continuing process that requires persistent arbitration by organizations in order to generate compulsions and states of shared interdependence (Cropanzano \& Mitchell, 2005; Saks, 2006) and this involves extensive cultural strategies inclusive of all levels of the organization. We also assert that our findings should induce managers to take pride in their subordinates' achievements and jointly fix key responsibility areas of the subordinate. This would induce favourable perceptions regarding justice and social exchange among organizational members and keep them more engaged.

Clearly, these implications would apply in any environment - but, more so in a volatile economic environment such as India, which has been characterized by tremendous growth and change the last two decades or so. In addition to addressing company policies and practices, organizations also need to ensure that managers are trained to change with the times, and be open to modifying their managerial styles and beliefs, something that is often easier said than done. Finally, Indian managers may need to start thinking of being managers first, and Indians second, 
as this is often the stumbling block that prevents the adoption of relevant global practices and policies.

\section{Limitations and Conclusion}

This study was confined to managers and executives in India. To confirm the cogency of our findings, comparative cross-cultural research may be conducted. The study, also being crosssectional may limit the consistency of findings over time. Replicating the meditational model tested here using a longitudinal design would be helpful in establishing causality among the constructs. While we included several variables at the individual level, future research may also consider multi-level conceptualization linking the individual level constructs of the present study to organizational level variables such as organizational culture and structure and their interactions with organizational justice, POS, and psychological contract in predicting employee engagement. Our sample represented employees from various firms in service and manufacturing sectors; however, the immediate work environment could differ significantly across firms and industries. Furthermore, organizational justice and POS have historically showed marked difference when grouped by gender. Hence separate models based on gender could check for their explanatory power. Finally, we focused solely on managers as being the agents enacting organizational procedures. Future research could investigate the extent to which our results generalize to other organizational agents such as team members and coworkers. Such research would be specifically significant for organizations that move towards implementing self-managed teams, as in emerging informational technology (IT) and IT enabled services companies. Future research could also investigate the relationships between the various forms of justice perceptions and the dimensions of psychological contract such as, transactional and relational contracts.

In conclusion, our study supports the inclusion of distributive justice, procedural justice, POS, and psychological contract in models of employee engagement. The results have important 
implications for assisting managers and companies to better understand and control factors that may lead to improved levels of employee engagement. 


\section{References}

Adams, J. S. (1965). Inequity in social exchange. In L. Berkowtz (Ed.), Advances in experimental social psychology (vol. 2: 267-299). New York: Academic Press.

Ang, S., Dyne, L. V., and Begley, T. (2003). The employment relationships of foreign workers versus local employees: A field study of organizational justice, job satisfaction, performance, and OCB. Journal of Organizational Behavior, 24, 561-583.

Aroian, L. A. (1944). The probability function of the product of two normally distributed variables. Annals of Mathematical Statistics, 18, 265-271.

Aselage, J. , \& Eisenberger, R. (2003). Perceived organizational support and psychological contracts: A theoretical integration. Journal of Organizational Behavior, 24, 491-509.

Atkouf, O. (1992). Management and theories of organization in the 1990s: Toward a critical radical humanism. Academy of Management Review, 17, 407-431.

Avolio, B. J., Zhu, W., Koh, W., and Bhatia, P. (2004). Transformational leadership and organizational commitment: Mediating role of psychological empowerment and moderating role of structural distance. Journal of Organizational Behavior, 25, 951-968.

Bentler, P M. (1990). Comparative fit indexes in structural models. Psychological Bulletin, 107(2), 238-246.

Bentler, P. M., \& Bonett, D. G. (1980). Significant tests and goodness of fit in the analysis of covariance structures. Psychological Bulletin, 88, 588-606.

Bhatnagar, J., \& Biswas, S. (2010). A conceptual proposal of the predictors and outcomes of employee engagement: Implications for the resource based view perspective. Indian Journal of Industrial Relations, 46, 273-286. 
Bies, R. J. (2005). Are procedural justice and interactional justice conceptually distinct? In J. Greenberg and J. A. Colquitt (Eds.), Handbook of organizational justice (pp. 85-112). Mahwah, NJ: Lawrence Erlbaum.

Biswas, S., \& Varma, A. (2007). Psychological climate and individual performance in India: Test of a mediated model. Employee Relations, 29, 664-676.

Biswas, S., Giri, V. N., \& Srivastava, K. B. L. (2006). Examinig the role of HR practices in improving individual performance and organizational effectiveness. Management and Labour Studies, 31, 111-133.

Blau, P. (1964). Exchange and power in social life. New York: Wiley.

Bowen, D. E., \& Osrtoff, C. (2004). Understanding HRM-firm performance linkagesw: The role of the "strength" of the HRM system. Academy of Management Review, 29, 203-221.

Boxall, P. \& Purcell, J. (2000). Strategic human resource management: where have we come from and where should we be going. International Journal of Management_Review, 2, 183-203.

Brockner, J. (2002). Making sense of procedural fairness: How high procedural fairness can reduce or heighten the influence of outcome favorability. Academy of Management Review, 27, 58-76.

Browne, M. W., \& Cudeck, R. (1993). Alternative ways of assessing model fit. In K.A. Bollen \& K. Long (Eds.), Testing structural equation models (pp. 136-162). Newbury Park, CA: Sage.

Browne, M. W., \& Cudeck, R. (1989). Single sample cross-validation indices for covariance structures. Multivariate Behavioral Research, 24, 445-455.

Budhwar, P. (2001). Doing business in India. Thunderbird International Business Review, 43, $549-568$. 
Budhwar, P., \& Sparrow, P. R. (1998). National factors determining Indian and British HRM practices: An empirical study. Management International Review, 38, 105-121.

Budhwar, P., \& Varma, A. (Eds.) (2011). Doing business in India. London, UK: Routledge.

Byrne, Z. S., \& Cropanzano, R. (2001). The history of organizational justice: The founders speak. In R. Cropanzano (Ed.), Justice in the workplace: From theory to practice (vol. 2: 3-26). Mahwah, NJ: Lawrence Erlbaum.

Cohen-Charash, Y., \& Spector, P. E. (2001). The role of justice in organizations: A metaanalysis. Organizational Behavior and Human Decision Processes, 86, 278-321.

Colquitt, J. A. (2001). On the dimensionality of organizational justice: A construct validation of a measure. Journal of Applied Psychology, 86, 386-400.

Colquitt, J. A., \& Chertkoff, J. M. (2002). Explaining injustice: The interactive effects of explanation and outcome on fairness perceptions and task motivation. Journal of Management, 28, 591-610.

Colquitt, J. A., Conlon, D. E., Wesson, M. J., Porter, C., \& Ng, K. Y. (2001). Justice at the millennium: A meta-analytic review of 25 years of organizational justice research. Journal of Applied Psychology, 86, 425-445.

Colquitt, J. A., Greenberg, J., \& Scott, B. A. (2005). Organizational justice: Where do we stand. In J. Greenberg and J. A. Colquitt (Eds.), Handbook of organizational justice (pp. 589619). Mahwah, NJ: Erlbaum.

Colquitt, J. A., Scott, B. A., Judge, T. A., \& Shaw, J. C. (2006). Justice and personality: Using integrative theories to derive moderators of justice effects. Organizational Behavior and Human Decision Processes, 100, 110-127.

Coyle-Shapiro, J. A. M., \& Conway, N. (2004). The employment relationship through the lens of social exchange. In J. A. M. Coyle-Shapiro, L. M. Shore, M. Taylor, and L. E. Tetrick 
(Eds.), The employment relationship: Examining psychological and contextual perspectives (pp. 5-28). Oxford: Oxford University Press.

Cropanzano, R., \& Mitchell, M. S. (2005). Social exchange theory: An interdisciplinary review. Journal of Management, 31, 874-900.

Cropanzano, R., Prehar, C., \& Chen, P. Y. (2002). Using social exchange theory to distinguish procedural justice from interactional justice. Group and Organizational Management, 27, 324-351.

Eisenberger, R., Armeli, S., Rexwinkel, B., Lynchh, P. D., \& Rhoades, L. (2001). Reciprocation of perceived organizational support. Journal of Applied Psychology, 86, 42-51.

Eisenberger, R., Huntington, R., Hutchison, S., \& Sowa, D. (1986). Perceived organizational support. Journal of Applied Psychology, 71, 500-507.

Fiske, S. T., \& Taylor, S. E. (1984). Social cognition. Reading, MA: Addison-Wesley.

Folger, R., \& Cropanzano, R. (1998). Organizational justice and human resource management. Thousand Oaks, CA: Sage.

Goodman, L. A. (1960). On the exact variance of products. Journal of the American Statistical Association, 55, 708-713.

Greenberg, J. (1990). Organizational justice: Yesterday, today, and tomorrow. Journal of Management, 16, 399-432.

Greenberg, J., \& Scott, K. S. (1996). Why do workers bite the hands that feed them? Employee theft as a social exchange process. In B. M. Staw and L. L. Cummings (Eds.), Research in Organizational Behavior (18: 111-156). Greenwich, CT: JAI Press.

Hofstede, G. (2001). Culture's consequences (2nd Ed.). Thousand Oaks, NJ: Sage Publications. Hu, L. T., \& Bentler, P. M. (1999). Cutoff criteria for fit indexes in covariance structure analysis: Conventional criteria versus new alternatives. Structural Equation Modeling, 6(1), 1-55. 
Iacobucci, D., Saldanha, N., \& Deng, X. (2007). A mediation on mediation: Evidence that structural equations models perform better than regressions. Journal of Consumer Psychology, 17, 140-154.

James, L. R., \& Brett, J. M. (1984). Mediators, moderators, and tests for mediation. Journal of Applied Psychology, 69, 307-321.

James, L. R., Mulaik, S. A., \& Brett, J. M. (1982). Causal analysis: Assumptions, models, and data. Beverley Hills, CA: Sage.

Kashyap, V., Ribeiro, A. H. P., Asare, A., \& Brashear, T. G. (2007). Developing sales force relationalism: The role of distributive and procedural justice. Journal of Personnel Selling \& Sales Management, 27, 33-43.

Kenny, D. A., Kashy, D. A., \& Bolger, N. (1998). Data analysis in social psychology. In D. Gilbert, S. T. Fiskey, \& G. Lindzey (Eds.), Handbook of social psychology (vol. 1, pp. 233-265). New York, NY: McGraw-Hill.

Konovsky, M. A., \& Cropanzano, R. (1991). Perceived fairness of employee drug testing as a predictor of employee attitudes and job performance. Journal of Applied Psychology, 76, 698-707.

Kuvaas, B. (2008). An exploration of how the employee-organization relationship affects the linkage between perceptions of developmental human resource practices and employee outcomes. Journal of Management Studies, 45, 1-25.

Loi, R., Hang-yue, N., \& Foley, S. (2006). Linking employees' justice perceptions to organizational commitment and intentions to leave: The mediating role of organizational support. Journal of Occupational and Organizational Psychology, 79, 101-120. 
MacKinnon, D. P., Lockwood, C. M., Hoffman, J. M., West, S. G., \& Sheets, V. (2002). A comparison of methods to test mediation and other intervening variable effects. Psychological Methods, 7, 83-104.

MacKinnon, D. P., Warsi, G., Dwyer, J. H. (1995). A simulation study of mediated effect Manogran, P., Stauffer, J., \& Conlon, E. J. (1994). Leader-member exchange as a key mediating variable between employees' perceptions of fairness and organizational citizenship behaviors. Paper present at the annual meeting of the Academy of Management, Dallas.

Masterson, S. S., Lewis, K., Goldman, B. M., \& Taylor, M. S. (2000). Integrating justice and social exchange: The differing effects of fair procedures and treatment on work relationships. Academy of Management Journal, 43, 738-748.

McBain, R. (2007). The practice of engagement: Research into current employee engagement practice. Strategic HR Review 6, 16-19.

Moorman, R. H., Blakely, G. L., \& Niehoff, B. P. (1998). Does perceived organizational support mediate the relationship between procedural justice and organizational citizenship behavior? Academy of Management Journal, 41, 351-357.

Ngo, H. Y., Tang, C. S., \& Au, W. W. (2002). Behavioral responses to employee discrimination: A study of Hong Kong workers. International Journal of Human Resource Management, 13, 1206-1223.

Niehoff, B. P., \& Moorman, R. A. (1993). Justice as a mediator of the relationship between methods of monitoring and organizational citizenship behavior. Academy of Management Journal, 36, 527-556.

Pillai, R., Williams, E. S., \& Tan, J. J. (2001). Are the scales tipped in favor of procedural or distributive justice? An investigation of the U.S., India, Germany, \& Hong Kong (China). International Journal of Conflict Management, 12, 312-332. 
Podsakoff, P. M., MacKenzie, S. B., Lee, J. Y., and Podsakoff, N. P. (2003). Common method bias in behavioral research: A critical review of the literature and recommended remedies. Journal of Applied Psychology, 88, 879-903.

Raja, U., Johns, G., \& Ntalianis, F. (2004). The impact of personality on psychological contracts. Academy of Management Journal, 47, 350-367.

Rhoades, L., \& Eisenberger, R. (2002). Perceived organizational support: A review of literature. Journal of Applied Psychology, 87, 698-714.

Rousseau, D. M. (1995). Psychological contracts in organizations. Thousand Oaks, CA: Sage.

Rupp, D. E., \& Cropanzano, R. (2002). The mediating effects of social exchange relationships in predicting workplace outcomes for multifoci organizational justice. Organizational Behavior and Human Decision Processes, 89, 925-946.

Saks, A. M. (2006). Antecedents and consequences of employee engagement. Journal of Managerial Psychology, 21, 600-619.

Schaufeli, W. B., \& Baker, A. B. (2004). Job demands, job resources, and their relationship with burnout and engagement: A multi-sample study. Journal of Organizational Behavior, 25, 293-315.

Settoon, R. P., Bennett, N., \& Liden, R. C. (1996). Social exchange in organizations: Perceived organizational support, leader-member exchange, and employee reciprocity. Journal of Applied Psychology, 81, 219-227.

Sobel, M. E. (1982). Asymptotic intervals for indirect effects in structural equation models. In S.

Leinhart (Ed.), Sociological methodology (pp.290-312). San Francisco, CA: Jossey-Bass.

Sparrow, P. R., \& Budhwar, P. (1997). Competition and change: Mapping the Indian HRM recipe against worldwide patterns. Journal of World Business, 32, 224-242.

Tekleab, A. G., Takeuchi, R., \& Taylor, M. S. (2005). Extending the chain of relationships 
among organizational justice, social exchange, and employee reactions: The role of contract violations. Academy of Management Journal, 48, 146-157.

Thibaut, J., \& Walker, L. (1975). Procedural justice: A psychological analysis. Hillsdale, NJ: Erlbaum.

Tsui, A. S., Pearce, J. L., Porter, L. W., \& Hite, J. P. (1995). Choice of employee-organizational relationship: Influence of external and internal organizational factors. In G. Ferris (Ed.), Research in personnel and human resource management (vol. 13: 117-151). Greenwich, CT: JAI Press.

Wood, R. E., Goodman, J. S., Beckmann, N., \& Cook, A. (2008). Mediation testing in management research: A review and proposals. Organizational Research Methods, 11, 270-295.

Yadapadithaya, P. S. (2000). International briefing 5: Training and development in India. International Journal of Training and Development, 4, 79-89. 
Table 1. Descriptive Statistics, Correlations, and Reliability Indices ( $=238)$

\begin{tabular}{lccccccc}
\hline \hline & Mean & S.D. & $\mathbf{1}$ & $\mathbf{2}$ & $\mathbf{3}$ & $\mathbf{4}$ & $\mathbf{5}$ \\
\hline 1. Distributive justice & 3.17 & .77 & $(.80)$ & & & & \\
2. Procedural justice & 3.08 & .72 & $.49 * *$ & $(.84)$ & & & \\
3. POS & 3.17 & .64 & $.32 * *$ & $.51 * *$ & $(.77)$ & & \\
4. Psychological contract & 2.93 & .42 & $.34 * *$ & $.50 * *$ & $.45 * *$ & $(.77)$ & \\
5. Employee engagement & 3.38 & .51 & $.01 *$ & $.39 * *$ & $.28^{* *}$ & $.30 * *$ & $(.82)$ \\
\hline
\end{tabular}

$* \mathrm{p} \leq .05 ; * * \mathrm{p} \leq .01$

Values in parentheses represent Cronbach's alpha 
Table 2. Regression Estimates

\begin{tabular}{lccc}
\hline \hline Variable Relationships & $\mathrm{b}$ & $\beta$ & C.R. \\
\hline Distributive justice $\rightarrow$ POS (H1) & .58 & .37 & 4.75 \\
Procedural justice $\rightarrow$ POS (H2) & .59 & .46 & 3.48 \\
Procedural justice $\rightarrow$ Psychological contract (H3) & .79 & .75 & 8.78 \\
POS $\rightarrow$ Employee engagement (H4) & .23 & .28 & 4.54 \\
Psychological contract $\rightarrow$ Employee engagement (H5) & .22 & .51 & 3.29 \\
\hline
\end{tabular}

Coefficients with C.R. $\geq \pm 1.95$ are significant at the $95 \%$ level of confidence and with C. R. $\geq \pm$ 2.58 are significant at the $99 \%$ level of confidence 
Table 3. LVM Fit Indices

\begin{tabular}{|c|c|c|c|c|c|c|c|c|c|c|}
\hline$L V M$ & GFI & NFI & RFI & IFI & TLI & CFI & AIC & $\begin{array}{l}\text { Browne- } \\
\text { Cudeck } \\
\text { Information } \\
\text { Criteria }\end{array}$ & RMSEA & $\begin{array}{c}\text { Normed } \\
\chi^{2}\end{array}$ \\
\hline $\begin{array}{l}\text { Proposed LVM } \\
(L V M 1)\end{array}$ & .95 & .95 & .89 & .99 & .97 & .99 & 484.85 & 523.38 & .04 & 1.36 \\
\hline $\begin{array}{l}\text { LVM without mediation } \\
\text { by Psychological contract } \\
(\text { LVM 2) }\end{array}$ & .68 & .64 & .59 & .69 & .64 & .68 & 1102.27 & 1111.69 & .14 & 5.46 \\
\hline $\begin{array}{l}\text { LVM without mediation } \\
\text { by POS (LVM 3) }\end{array}$ & .74 & .70 & .63 & .73 & .67 & .73 & 623.30 & 628.22 & .15 & 6.46 \\
\hline $\begin{array}{l}\text { LVM without any } \\
\text { mediation (LVM4) }\end{array}$ & .75 & .71 & .64 & .74 & .67 & .74 & 510.34 & 513.98 & .16 & 7.30 \\
\hline
\end{tabular}

Note: GFI = Goodness-of-Fit Index; CFI = Comparative Fit Index; NFI = Normed Fit Index; RFI = Relative Fit Index; IFI = Incremental Fit Index; TLI = Tucker-Lewis Index; RMSEA = Root Mean Square Error of Approximation; AIC = Akaike Information Criteria 
Table 4. Analysis of job satisfaction and job involvement as mediator variables

\begin{tabular}{|c|c|c|c|c|c|c|}
\hline & $\begin{array}{c}\text { Whether } \\
\text { (direct } \\
\text { path) > } \\
\text { (path } \\
\text { under } \\
\text { mediated } \\
\text { condition)? }\end{array}$ & $\begin{array}{c}\text { Whether } \\
\text { (path } \\
\text { under } \\
\text { mediated } \\
\text { condition) } \\
\text { is } \\
\text { significant? }\end{array}$ & $\begin{array}{l}\text { Results of } \\
\text { the mediator } \\
\text { analysis }\end{array}$ & $\begin{array}{c}\text { Sobel's } \\
\text { Test }\end{array}$ & $\begin{array}{c}\text { Aroian's } \\
\text { Test }\end{array}$ & $\begin{array}{c}\text { Goodman's } \\
\text { Test }\end{array}$ \\
\hline $\begin{array}{l}\text { Distributive } \\
\text { justice } \rightarrow \\
\text { POS } \rightarrow \text { Employee } \\
\text { engagement }\end{array}$ & No & Yes & $\begin{array}{c}\text { POS is a full } \\
\text { mediator }\end{array}$ & $3.28 * *$ & $3.24 * *$ & $3.32 * *$ \\
\hline $\begin{array}{l}\text { Procedural } \\
\text { justice } \rightarrow \text { POS } \rightarrow \\
\text { Employee } \\
\text { engagement }\end{array}$ & No & Yes & & $2.76 * *$ & $2.72 * *$ & $2.81 * *$ \\
\hline $\begin{array}{l}\text { Procedural } \\
\text { justice } \rightarrow \\
\text { Psychological } \\
\text { contract } \rightarrow \\
\text { Employee } \\
\text { engagement }\end{array}$ & No & Yes & $\begin{array}{l}\text { Psychological } \\
\text { contract is a } \\
\text { full mediator }\end{array}$ & $3.08 * *$ & $3.06^{* *}$ & $3.10 * *$ \\
\hline
\end{tabular}

$* * \mathrm{p} \leq .01$ 


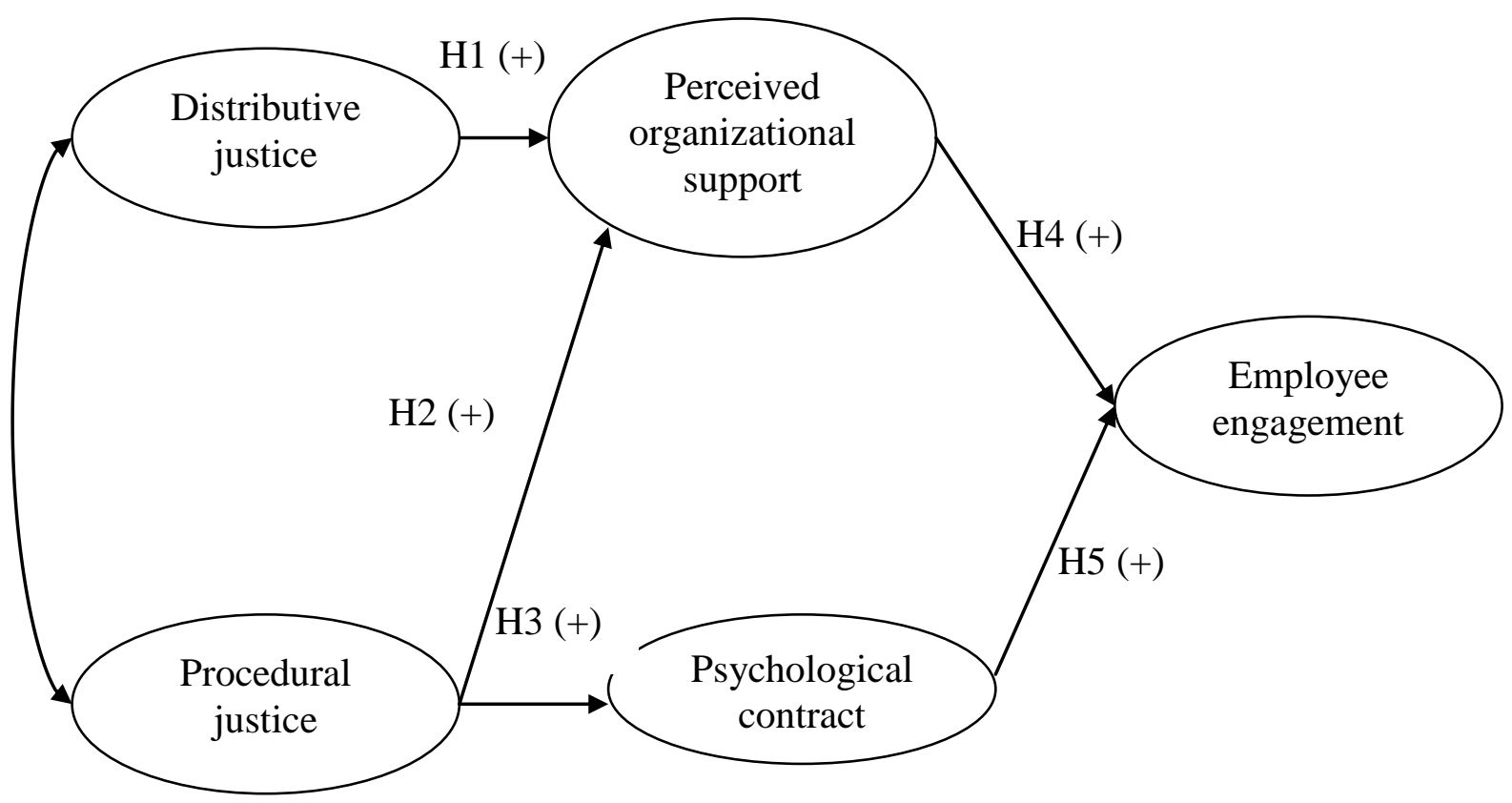

Figure 1. The conceptual model (LVM1)

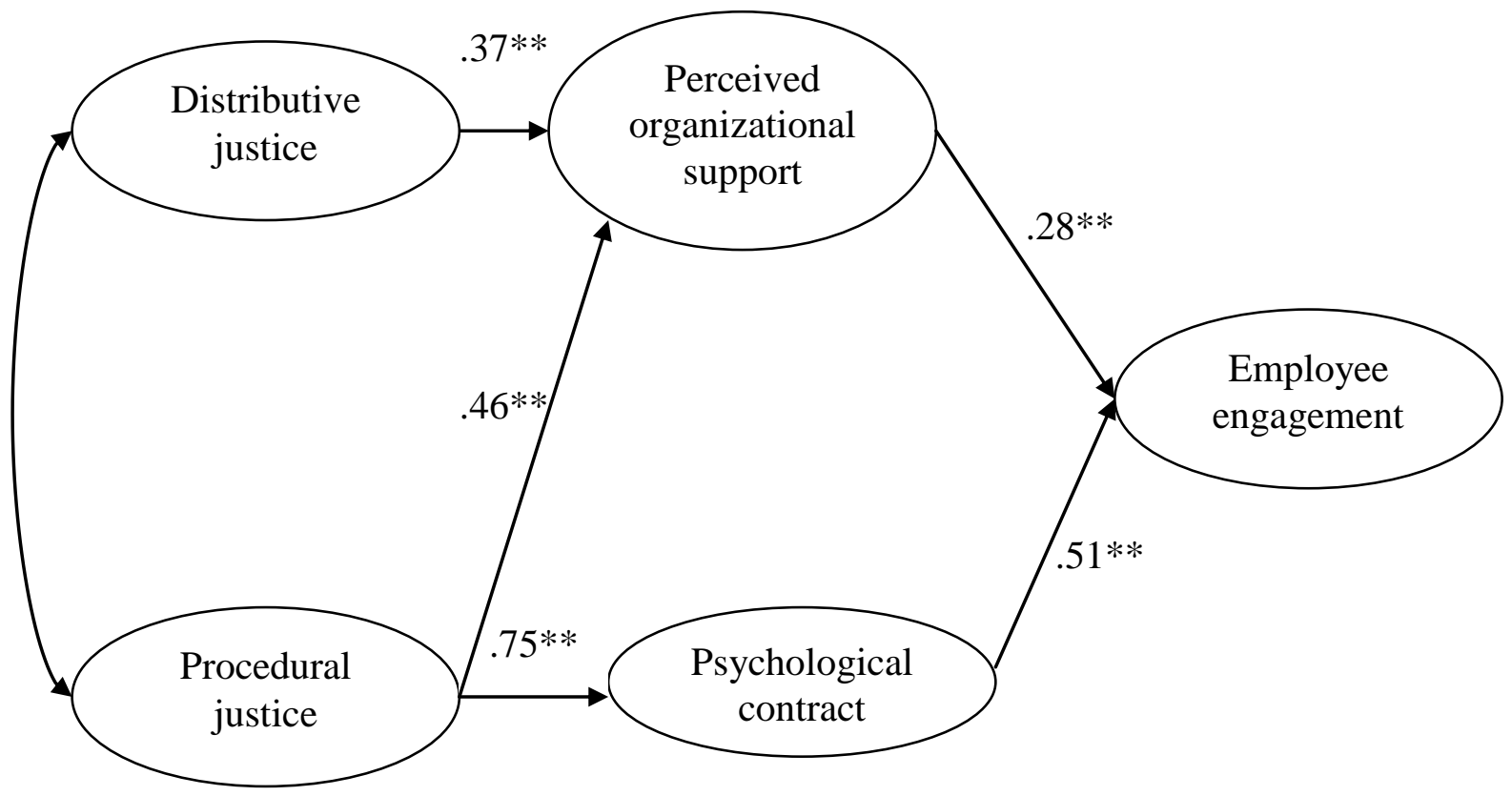

Figure 2. The path coefficients of LVM1 $* * p \leq .01$ 


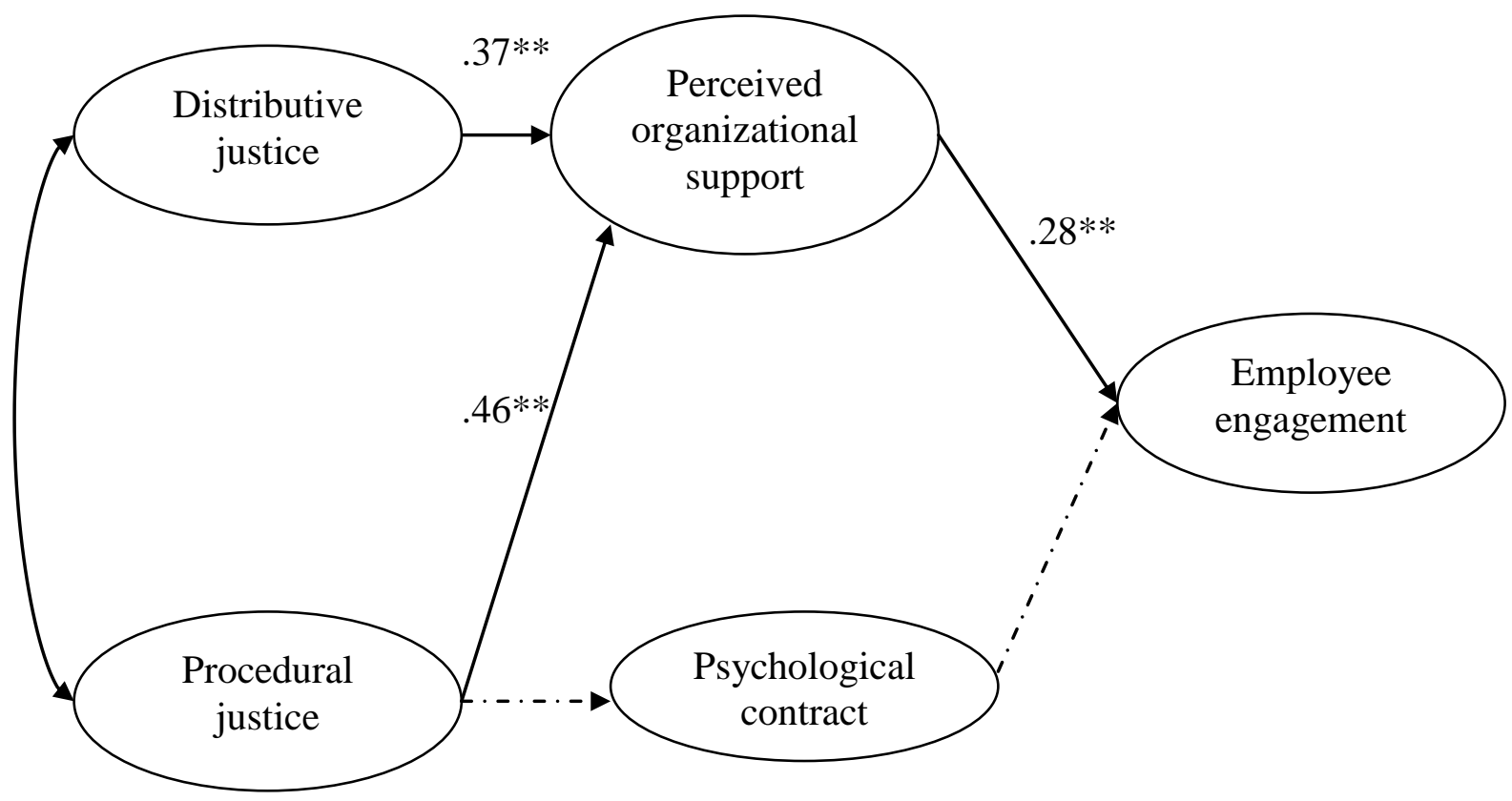

Figure 3. The model constraining Psychological contract (LVM2) $* * p \leq .01$

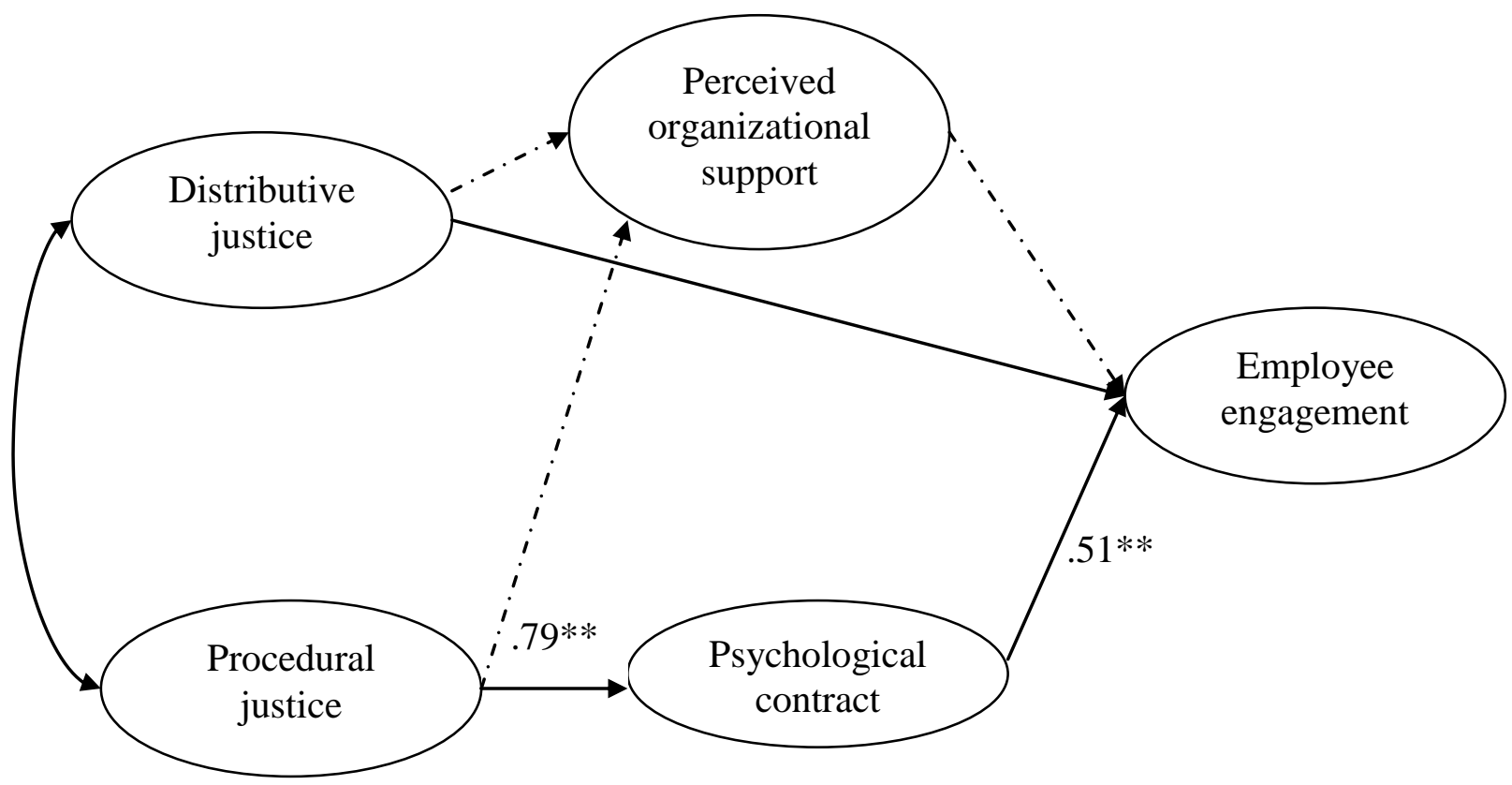

Figure 4. The model constraining POS (LVM3) $* * p \leq .01$ 


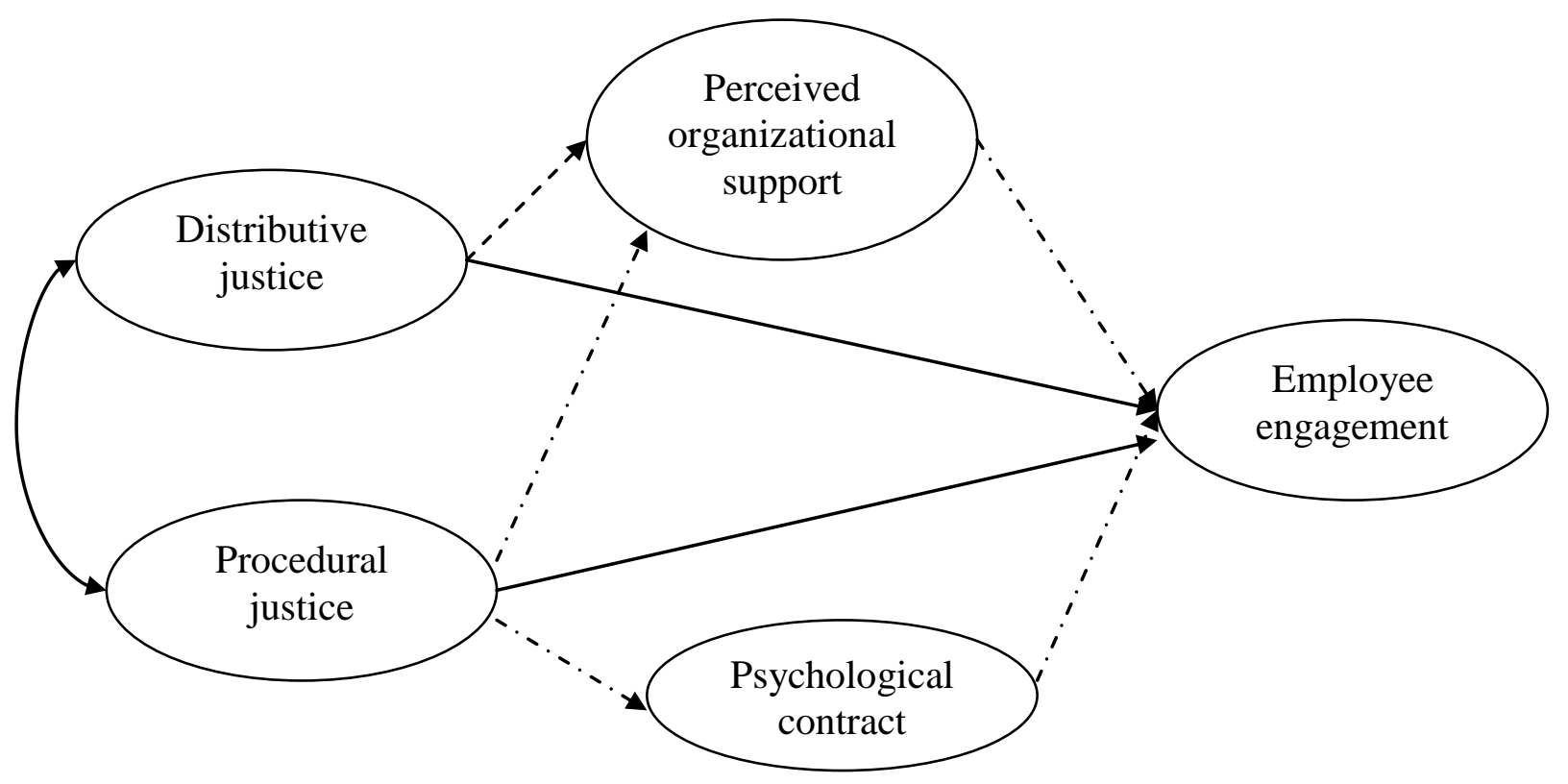

Figure 5. The model without mediation (LVM4) 